\title{
Protocol Deviation Category
}

National Cancer Institute

\section{Source}

National Cancer Institute. Protocol Deviation Category. NCI Thesaurus. Code C87990.

A classification of protocol deviation data. 